\title{
Stakeholder Partnership in the Management of Marine Tourism in South Lampung Regency, Lampung
}

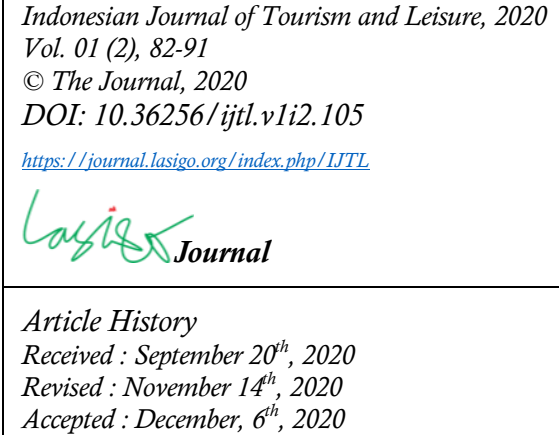

\section{Rahayu Sulistiowati}

Department of Public Administration, Faculty of Social and Political Sciences, Universitas Lampung Email: rahayu.sulistiowati@fisip.unila.ac.id

\section{Meiliyana}

Department of Public Administration, Faculty of Social and Political Sciences, Universitas Lampung Email: meiliyana@fisip.unila.ac.id

\section{Syamsul Ma'arif}

Department of Public Administration, Faculty of Social and Political Sciences, Universitas Lampung Email: syamsul.maarif@fisip.unila.ac.id

\section{Selvi Diana Meilinda}

Department of Public Administration, Faculty of Social and Political Sciences, Universitas Lampung Email: selvi.meilinda@fisip.unila.ac.id

\begin{abstract}
Tourism management must involve stakeholders who each play a role in increasing tourist visits. Although several research have been pointed out the stakeholder's role in tourism management, the research on the context of marine tourism is still a few. This research aims to analyze stakeholder partnerships in the management of marine tourism in Lampung Selatan Regency. It is important to map engaged actors in the tourism management. The results show that there are 12 stakeholders who partnered and had their respective roles. Stakeholders involved in the management of nature tourism based on interests and influences in South Lampung consist of: a) Key Player, namely Tourism Agency; b) Subject, namely PT Kahaii (Private company) and the community who own beach tourism objects, c) Context Setter, namely NGOs, Indonesian Tour Guide Association (HPI) and Travel Agent Association (ASITA), Indonesian Recreational Park Business Association (PUTRI) and Event Organizer Association (AEO), Community Groups or Pokdarwis, Pokdarwis Communication Forum, KPK (Krakatau Putera Community), d) Crowd namely, Culture Office, Regional Development Planning Agency, Public Works Office, and the community.
\end{abstract}

Keywords: Partnership; Stakeholders; Marine Tourism

\section{Introduction}

The tourism sector in South Lampung Regency, especially marine tourism, has promising prospects, but the level of tourist visits, especially foreign tourists, is remain low. Various efforts to develop marine tourism are carried out by the government and the community to introduce the 
tourism potential and to increase tourist visits, both local and foreign tourist, but the synergy between government and private business actors and civil society (NGOs and community group of tourism management or called by Pokdarwis) has not been optimal. The development of the tourism sector cannot only be carried out by the government, it needs the involvement of private tourism business actors and non-government or civil society organizations that work together to advance tourism development (Hilman \& Kartika, 2020; Yudiatmaja, 2016; Yudiatmaja, Safitri, et al., 2017)

The potential for marine tourism in South Lampung has not yet fully developed and developed the economy of the local community. The lack of infrastructure funds in developing tourism potential is one of the reasons for tourism in South Lampung, such as on-site roads and no development. In addition, the community's concern for the environment and maintaining the comfort and tranquility of everyone who comes to South Lampung tours is still lacking. In fact, this is a concrete form of public participation in tourism development in South Lampung.

Tourist visits to marine tourism objects in South Lampung are fluctuating but there is trend to be an increase from year to year as seen in Table 1. It depicts that tourism is a potential source developed by the government of South Lampung.

Table 1. The Number of Tourists in South Lampung

\begin{tabular}{lc}
\hline Year & Number of Tourist Visited \\
\hline 2012 & 138.410 \\
2013 & 72.950 \\
2014 & 98.030 \\
2015 & 120.250 \\
2016 & 127.150 \\
2017 & 139.885 \\
\hline
\end{tabular}

Source: Tourism Board of Lampung Selatan Regency (2019)

From these data, it can be seen that tourist visits to a number of marine tourism spots in Lampung Selatan Regency are fluctuating but in the last three years there has been an increase. Although there is an increase in the number of tourists visiting a number of beaches or known as marine tourism, this number is still very small compared to the potential of the area and compared to tourists who come to other areas that also have beautiful beaches such as in Java and especially Bali. The geostrategic position of Lampung Province and South Lampung in particular has not maximally influenced tourist arrivals (Higgins-Desbiolles, 2018).

To increase tourist visits, it is necessary to have a strategy carried out by related agencies or parties in order to achieve these goals and one of the strategies carried out is a partnership between stakeholders in South Lampung which is related to tourism issues. The stakeholders have an essential role in developing tourism (Alonso \& Nyanjom, 2017; Mahadiansar \& Aspariyana, 2020). For this reason, this research was conducted in order to describe the strategic partnership in the management of marine tourism in the South Lampung.

Stakeholder analysis is one of the methods used to identify stakeholders who have a role in decision making, know the interests and influence of stakeholders, map the relationships between parties based on the magnitude of the influence and interests of each stakeholder and the understanding of stakeholders in organizational development (Reed et al., 2009; Yudiatmaja, 2012). Stakeholders can be grouped into 4 groups based on their level of importance and influence. Stakeholders are grouped based on their level of interest and influence, among others: (1) Key Player, is the most active stakeholder in management because these stakeholders have large interests and influence. (2) Subject, is a stakeholder who has a big interest, but has little influence. Stakeholders of this type are supportive, have little capacity to change the situation. 
This stakeholder may be influenced by other stakeholders. (3) Context Setter, is a stakeholder who has a big influence, but has little interest. Stakeholders of this type are likely to present significant harm, so they must be monitored and managed. (4) Crowd, is a stakeholder with little interest and influence. These stakeholders will consider all the activities they do.

\section{Literature Review}

The collaboration network that is formed between stakeholders is then commonly known as a partnership. Etymologically, partnership comes from the root word partner. Partner can be defined as partner, mate, ally or companion. Meanwhile, partnership is translated as partnership or partnership. Thus, a partnership can be interpreted as a form of alliance between two or more parties that form a cooperation bond in a particular business field or a specific goal so that it can get better results (Sloan \& Oliver, 2013).

The concept of a network is built on the idea of a "connectedness" or connection (Firdaus et al., 2019). The point is that there is a relatively stable line of communication between individual members of the organization. This network theory is related to organizational communication or is a sub of organizational communication, because in essence individuals who communicate with each other will be connected to each other in groups which will eventually form an entire network (Marques, 2010). Such a network is known as an intra-organizational network or a network within an organization. Likewise, when an organization communicates with other organizations, the lines of relationships between organizations are created that make the organization connected to one another to form an inter-organizational network.

With regard to multi-stakeholder partnerships, MacDonald et al. (2019) defined it as a form of cooperation based on voluntary agreements, mutual need, togetherness and active participation of stakeholders from a wide spectrum of institutions, including government, business sector, community civil society and NGOs (NGOs) and other parties that have direct interests in the issues that are cooperated. A multi-stakeholder partnership can be in the form of a formal or informal partnership depending on the existence, type and content of the cooperation agreement clause and the type of institution that has been decided together. Through this collaboration, all stakeholders share risks and combine their human, financial, knowledge and experience resources to maximize their potential in achieving common goals.

In the context of this research, understanding the partnership requires an analysis of the stakeholders involved. Lyon et al. (2017) describes stakeholder mapping as a collaborative process that includes research, debate, and discussion to determine the main list of stakeholders from a broad spectrum of stakeholders. For this reason, according to Golini et al. (2017), there are several stages that are passed in the stakeholder analysis, namely: (1) Stakeholders' Interest Level; (2) Stakeholders Influence and Interests; (3) Identification of the Roles of Stakeholders.

\section{Method}

This research used a qualitative approach. It was conducted in South Lampung Regency, Lampung. The research was conducted for 3 months, from August to November 2019. The tools and materials used in the study included: interview guides, gadgets, stationery. The technique of determining informants in this study used purposive sampling. Informants were considered as actors (agencies or institutions or groups) who involve in the management of marine tourism in South Lampung. Data collection methods used in identifying and classifying stakeholders included: (a) Interviews that used semi-structured interviews to key informants from each stakeholder. (b) Field observation. (c). Document tracing, by carried out on strategic plan documents (document of strategic management belongs to government of South Lampung), job descriptions of Government agency, government policies on tourism, and other documents relevant. Document tracing was carried out as a first step in research and was needed to assist data analysis. Data analysis used stakeholder analysis and descriptive analysis. 


\section{Results}

In many countries or regions, tourism is a chosen policy, not a policy driven by demands such as policies to address food or housing needs. The positioning of the tourism sector in regional development is very important as a starting point for formulating policies. Linda Richer in her said that what happens can be wrong or right, but what is clear is that the success or failure of tourism is very much influenced by political and administrative actions and not because of economic and business expertise (Richter, 1983).

Currently competition among tourist destinations in the international world and particularly in Indonesia is getting tighter. In order to be competitive, each destination is racing to provide a quality experience and create the best value for its visitors while managing and managing the impact of tourism on local communities and the environment. Improving service quality and creating the best value are closely related to the availability of good tourism products and the ease of movement of tourists into and within tourist destination.

Tourism products are all the facilities needed by tourists from leaving the house to returning home, so that the provision of tourism products requires the support of many parties. The management of tourist destinations involves many parties in line with the characteristics of this sector. Tourism is a service industry that has unique multidimensional characteristics (multisector, multi-actor, multi-regional and multi-aspect). The multidimensional character of tourism causes this sector to depend heavily on integrated management so that tourism development goals are achieved.

Development planning and regional tourism institutions generally refer to several regional planning documents what they named as mid-term strategic plan, city spatial planning, and local tourism master plan. In this document, tourism planning usually is not comprehensive (only per field). Local governments that have been successful in developing their tourism are very aware of the multidimensional character of the tourism sector, so that the tourism planning approach is carried out in a multi-sector manner as well. As has been done by the Belitung Regency Government, in its regional development it is always through a thematic approach-holistic.

Thematic here define as an action arrange by local government, for instance if a coordination meeting is to be held, it always raises a theme that supports tourism development, then it is discussed collectively or thoroughly from each unit related. Through this pattern, tourism will become the "spirit" of development in each unit, in other words tourism will become an integral part of regional development as a whole (María \& Michael, 2012).

Regional tourism development has not been based on long-term plans, it is still very much dependent on political policies', depends on willingness of the leaders at that time. Tourism development planning documents, such as: local tourism master plan or tourism local regulation, have not been used as the main reference in regional tourism development. Various obstacles such as the low quality of planning documents and the weak commitment of relevant stakeholders in building collective agreements. This causes various regional development policies in the tourism sector remain weak, for example: weak on coordination between sectors, no guarantees for the private sector or investors about the direction of regional tourism development and so on. Forms or patterns and mechanisms for managing tourism destinations are still partial, not involving many parties, so they do not support the unique character of tourism which is multidimensional (Ansell \& Gash, 2008).

Tourism development involves many parties in the government and the private sector. In addition to current public and private tourism organizations that are horizontal and vertical, diagonal tourism organizations are also needed. Among entrepreneurial an organization that covers various types of businesses is needed (Kapera, 2018; Scheyvens \& Biddulph, 2018). Another organization that is needed is a community organization that can be the front liner for 
effective empowerment efforts and also functions as a social controller. Problems as described above were also found in the research location.

The partnership between stakeholders involved in developing marine tourism in South Lampung district is described as follows:

\subsection{Identification of Stakeholders and Their Roles}

The number of stakeholders involve on marine tourism management in South Lampung is 12 stakeholders. Stakeholders involve come from provincial and district government agencies, private institutions, community groups, individual entrepreneurs, and the community. The roles of government agencies in managing marine tourism includes protecting resources, empowering local communities, providing tourism services, and providing data and information on marine tourism. The role of government agencies in protecting resources is carried out through environmental supervision of coastal tourism areas. Meanwhile their role in community empowerment is carried out through the formation of community group that has an awarness on tourism (Pokdarwis). Then, the government's role in providing tourism services is carried out by build and maintain roads to tourist objects. However, this still raise complain from managers of private company such as Kahaii Resort. According to him, a very poor and small road to tourist attractions had an impact on the low number of visits to this location. There are cases that resulting in many tourist groups canceling their visits due to these conditions (results of observations and interviews, September, 2019). The government agencies' role on providing data and information is carried out through inventory or visits to tourist objects and published in various books, leaflets, and online media.

Meanwhile, the roles of private institutions on managing marine tourism in South Lampung district could be define as follows; community empowerment, providing tourism services, providing data and information. Their role for community empowerment is carried out through providing employment for local communities, providing guidance on the need to maintain the beauty of the coast in collaboration with NGO engaged in the tourism and environment sector, namely the KPK (Putra Krakatau Communications). Then their role on providing tourism services is carried out by providing lodging, restaurants, tourism programs, and other facilities needed by visitors. Last, their role on providing data and information is carried out through billboards, websites, leaflets and interpretation boards that explain about the beaches in the area.

The roles of community groups in marine tourism management includes protecting resources, empowering local communities and providing tourism services. Its role on resource protection is carried out through maintaining cleanliness and beauty of beaches, planting and maintaining mangroves. The role on community empowerment is carried out through persuasive counseling to maintain cleanliness and beauty of beaches. The role of providing tourism services is carried out by community groups.

Then the roles of individual entrepreneurs on managing marine tourism in South Lampung is to provide tourism services. The role of providing tourism services is carried out through the construction of hotel facilities, restaurants, mosque or prayer rooms, toilets and all necessary facilities in coastal tourism areas. They also creat food stalls within the coastal tourism area and along the road to these tourist sites.

\subsection{Stakeholder Partnership Mapping}

Key players are stakeholders who have great interest and influence and are most active in management (Reed et al. 2009). The stakeholder categorized as the key player group in the management of marine tourism in South Lampung district is the South Lampung Tourism and Culture Office. This is because Tourism and Culture Office of South Lampung is a regional government agency that is mandated to carry out local government affairs in the field of culture and tourism in Tourism and Culture Office. So that all-natural resources belonging to the local 
government which will be used as marine tourism objects must go through the approval of the Tourism and Culture Office of South Lampung.

Subjects are stakeholders who have big interests but little influence. This type of stakeholder is supportive but has little capacity to change the situation (Reed et al. 2009). Stakeholders who are categorized in the subject group are PT Kahaii, and community owners of beach tourism objects. The subject group has a high importance because it carries out direct management of the beach tourism objects that they have in the form of building facilities, making tourism programs, marketing, and handling environmental pollution from coastal tourism activities. The management aims to attract visitors to the beach tourism objects they have. The subject group has little influence due to a lack of collaboration with other stakeholders. The subject group only collaborates with the local community. Collaboration carried out with local communities is in the form of securing beach tourism objects.

Context setters are stakeholders who have a big influence but little interest (Reed et al. 2009). Stakeholders who are included in the context setter group are NGOs, the Association of Indonesian Tour Guides (HPI) and the Travel Agent Association (ASITA). Indonesian Recreation Park Business Association (PUTRI) and Event Organizer Association (AEO), Community Groups (Pokdarwis), Pokdarwis Communication Forum, KPK (Putera Krakatau Community).

Its influence to government agencies is carried out through opinions and suggestions in a tourism activity such as an exhibition. Influence on NGOs is exerted through cooperation in the form of projects in the maritime or maritime coastal sector. Influence to the community is given through counseling and guidance in planting mangrove seedlings.

Crowd is a stakeholder with little interest and influence. These stakeholders will consider all the activities they carry out (Reed et al., 2009). Stakeholders who are included in the crowd group are the Public Works Office of South Lampung, Culture Office of Lampung Province, Regional Development Planning Agency of South Lampung, HPI, PHRI, ASITA, and the community. Crowd groups have little interest and influence because most of their working areas are at the provincial level such as Culture Office of Lampung Province, HPI, PHRI, ASITA. So that the work programs of these stakeholders are not focused on South Lampung but for the entire Lampung Province. Stakeholders who have a working area in South Lampung such as the Regional Development Planning Agency also have little interest and influence because the agency is only involved in planning coastal tourism in South Lampung. Meanwhile, the Public Works Office whose role is to provide road access is general and not specifically for tourism purposes only. The community has little interest and influence because the community has not been able to take advantage of the opportunities for tourism objects to increase income, except as workers in tourist objects. In addition, the community is still considered as an object that is influenced not as a tourist activity.

In institutional development, it is not enough just to form a provincial or regency or city tourism office, but more importantly, in accordance with the characteristics of the multisectoral and multidimensional tourism sector, it is necessary to have a forum that brings together those various sectors. Furthermore, how the group coordinates and implements joint programs.

\section{Discussion}

Why partnership or collaboration is needed? The collaborative approach began to emerge in response to the demands of the need for new, democratic resource management, which recognizes the expansion of the human dimension in managing choices, managing uncertainty, the complexity of potential decisions and building understanding, supporting ownership of shared choices (Geiyono et al., 2018; Wondolleck \& Yaffee, 2000). Collaboration defines as a process in which two or more stakeholders with different interests in the same problem explore and work 
through differences to collectively seek solutions for mutual benefit (Gray, 1989; Pozlita et al., 2014).

The results of several studies show that the motivation of stakeholders to collaborate is that collaboration will provide positive results, the choice of achieving solutions for their interests, it is necessary to achieve a fair agreement among stakeholders, each stakeholder has the capacity to participate in management, other key stakeholders agree to collaborate (Gray, 1989; Yudiatmaja, Alfiandri, et al., 2017). Who collaborates? In the context of tourism, there are 5 key groups that can collaborate, which are: Academics, Businessmen, Community, Government and Media or known as "pentahelix" (ABCGM). In tourism, each of these stakeholders has a different role, although maybe in some ways there are intersections.

The role of the government is to prepare basic infrastructure and facilities that support tourism development, prepare various regulations related to tourism, facilitate the ease of traveling and endeavor and carry out promotional and marketing activities for destinations. Destination development and industrial development require clear and wise regulations and integrated institutions from both private and government parties. It can be identified the division of roles or who does what. The development of a tourism industry or business is of course carried out by the private sector and the government functions to facilitate and support it. The Provincial Government together with the Central and District or City Governments are tasked with developing the community and various kinds of public services needed so that tourism can be carried out in that place and the tourism industry can develop. In addition, the government plays a direct role in developing regulations, control the activities of developers and industry, and strengthen institutions for capacity building in formulating policies and making decisions at various levels of government.

Business (private or business world) acts as an organizer of tourism business in accordance with business ethics, professionalism, responsibility and sustainability. The role of the business sector as a "profit oriented" institution must also take responsibility for environmental sustainability as the main capital of tourism (Firdaus \& Tutri, 2017). Private partnerships with the community and government are needed in a "true" sense. A mutually beneficial (win-win) relationship must be built with formal and non-formal approaches. Several successful tourism destinations involve many parties as a result of built a non-formal approach between the private sector and the government.

Community which consist of communities (Local community and NGO). The community plays a role in supporting Sapta Pesona and provides tourism or creative economy services. The community is the object as well as subject of tourism itself, but on the other hand, society can become an obstacle to developing tourism in a destination. Therefore, people must know exactly what their role is and tourism is for their well-being. Continuous assistance from the government, NGOs and the private sector can increase the role of the community in regional tourism development (Samnuzulsari \& Yudiatmaja, 2015; Suyito et al., 2018).

Academicians who play a role in conducting various research and community service related to tourism development, so that tourism development can be done on research-based. Even though, sometimes research results are not used in tourism development. Various community services can be carried out by academicians in tourism development, therefore communication and collaboration with academicians in tourism development is needed.

The media, especially online media, are currently the power of information for tourism promotion. Tourism promotion and marketing can now be done quickly by utilizing social media. Promotion is now more inclusive, for example: tourists can upload testimonials of visiting a tourist attraction on social media. The form of collaboration in government, namely as a forum between institutions is Cross-Sectoral Coordination (McComb et al., 2017; Yudiatmaja, 2013b, 2013a). 
By seeing the importance of stakeholders working together, it is hoped that the management of tourism, especially marine tourism in South Lampung, will be better so that it will attract the interest of tourist visits to marine tourism destinations owned by the area.

\section{Conclusion}

Stakeholders involved in natural tourism management based on interests and influences consist of: a) Key Player, namely Tourism and Culture Office of South Lampung; b) Subject, namely PT Kahaii, and community owners of beach tourism objects, c) Context Setter, namely NGOs, the Association of Indonesian Tour Guides (HPI) and the Travel Agent Association (ASITA). The Indonesian Recreation Park Business Association (PUTRI) and the Event Organizer Association (AEO), Community Groups (Pokdarwis), Pokdarwis Communication Forum, KPK (Putera Krakatau Community); d) Crowd namely, Culture Office of Lampung Province, Regional Development Planning of South Lampung, Public Works Office of South Lampung, and general public.

The role of government agencies in managing marine tourism includes protection of resources; empowering local communities, providing tourism services, and providing data and information on natural tourism. The role of private institutions includes community empowerment, providing tourism services, providing data and information. The role of community groups includes protecting resources, empowering local communities, providing tourism services; the role of individual entrepreneurs and the community is to provide tourism services.

\section{Acknowledgment}

We thank the Faculty of Social and Political Sciences Universitas Lampung for funding and supporting this research.

\section{Funding}

This research was funded by the Faculty of Social and Political Sciences Universitas Lampung.

\section{Conflicts of Interest}

Authors declare no conflicts of interest of the article.

\section{References}

Alonso, A. D., \& Nyanjom, J. (2017). Local stakeholders, role and tourism development. Current Issues in Tourism, 20(5), 480-496.

Ansell, C., \& Gash, A. (2008). Collaborative governance in theory and practice. Journal of Public Administration Research and Theory, 18(4), 543-571. https://doi.org/10.1093/jopart/mum032

Firdaus, F., Ariesta, A., Rahayu, S., \& Shalihin, N. (2019). Market Organizer Network At Fish Auction; Case Study Of Gauang Market, Padang, West Sumatera, Indonesia. International Journal of Scientific \& Technology Research, 8(09), 37-41.

Firdaus, F., \& Tutri, R. (2017). Potensi Pengembangan Ekowisata Di Nagari Kotobaru, Kecamatan X Koto, Kabupaten Tanah Datar, Sumatera Barat. Jurnal Kawistara, 7(2), 115206. https://doi.org/10.22146/kawistara. 13570

Geiyono, S., Muhammad, A. S., \& Yudiatmaja, W. E. (2018). Kolaborasi dan manajemen pengetahuan dalam pengelolaan zakat, infak dan sedekah di Kota Tanjungpinang. In Jurnal Ilmu Administrasi Negara (Vol. 6, Issue 1). JUAN.

Golini, R., Corti, B., \& Landoni, P. (2017). More efficient project execution and evaluation with logical framework and project cycle management: Evidence from international development projects. Impact Assessment and Project Appraisal, 35(2), 128-138.

Gray, B. (1989). Collaborating: Finding common ground for multi-party problems. Jossey-Bass.

Higgins-Desbiolles, F. (2018). Sustainable tourism: Sustaining tourism or something more? Tourism Management Perspectives, 25(October 2017), 157-160. 
Hilman, Y. A., \& Kartika, T. (2020). Dinamika Kelembagaan Sektor Pariwisata di Kabupaten Ponorogo. Indonesian Journal of Tourism and Leisure, 1(1), 26-37. https://doi.org/10.36256/ijtl.v1i1.82

Kapera, I. (2018). Sustainable tourism development efforts by local governments in Poland. Sustainable Cities and Society, 40, 581-588.

Lyon, A., Hunter-Jones, P., \& Warnaby, G. (2017). Are we any closer to sustainable development? Listening to active stakeholder discourses of tourism development in the Waterberg Biosphere Reserve, South Africa. Tourism Management, 61, 234-247.

MacDonald, A., Clarke, A., \& Huang, L. (2019). Multi-stakeholder partnerships for sustainability: Designing decision- making processes for partnership capacity. Journal of Business Ethics, 160(2), 409-426.

Mahadiansar, M., \& Aspariyana, A. (2020). PEST Analysis Model dalam Pengembangan Potensi Wisata Pulau Benan, Kabupaten Lingga, Kepulauan Riau. Indonesian Journal of Tourism and Leisure, 1(1), 14-25. https://doi.org/10.36256/ijtl.v1i1.93

María, J. Z., \& Michael, H. C. (2012). Public-private collaboration in the tourism sector: balancing legitimacy and effectiveness in local tourism partnerships. The Spanish case. Journal of Policy Research in Tourism, Leisure and Events, Volum 4(Issue 1), 61-83.

Marques, J. F. (2010). Enhancing the quality of organizational communication: A presentation of reflection- based criteria. Journal of Communication Management, 14(1), 47-58.

McComb, E. J., Boyd, S., \& Boluk, K. (2017). Stakeholder collaboration: A means to the success of rural tourism destinations? A critical evaluation of the existence of stakeholder collaboration within the Mournes, Northern Ireland. Tourism and Hospitality Research, 17(3), 286-297.

Pozlita, P., Muhammad, A. S., \& Yudiatmaja, W. E. (2014). Jiwa Kewirausahaan di Sektor Publik (Studi Kasus Kepemimpinan Walikota Tanjungpinang 2013-2014). Jurnal Ilmu Administrasi Negara (JUAN), 2(2), 21-36.

Reed, M. S., Graves, A., Dandy, N., Posthumus, H., Hubacek, K., Morris, J., Prell, C., Quinn, C. H., \& Stringer, L. C. (2009). Who's in and why? A typology of stakeholder analysis methods for natural resource management. Journal of Environmental Management, 90(5), 1933-1949. https://doi.org/001

Richter, L. K. (1983). Tourism politics and political science: A case of not so benign neglect. Annals of Tourism Research, 10(3), 313-335.

Samnuzulsari, T., \& Yudiatmaja, W. E. (2015). Reformasi administrasi desa. Jurnal Ilmu Administrasi Negara (JUAN), 3(2), 36-41.

Scheyvens, R., \& Biddulph, R. (2018). Inclusive tourism development. Tourism Geographies, 20(4), 589-609.

Sloan, P., \& Oliver, D. (2013). Building trust in multi-stakeholder partnerships: Critical emotional incidents and practices of engagement. Organization Studies, 34(12), 1835-1868.

Suyito, Effendi, D., Yudiatmaja, W. E., Ghani, N. A., \& Abd Wahab, A. M. (2018). Peranan dan kontribusi lembaga swadaya masyarakat dalam agenda pemberantasan korupsi di Indonesia: Studi di Kota Tanjungpinang, Kepulauan Riau, Indonesia. Asian People Journal (APJ), 1(2), 146-161.

Tourism Board of Lampung Selatan Regency. (2019). The report of tourism visiting. South Lampung Government.

Wondolleck, J. M., \& Yaffee, S. L. (2000). Making collaboration work: Lessons from innovation in natural resource managment. Island Press.

Yudiatmaja, W. E. (2012). Dinamika administrasi negara kontemporer: Konsep dan isu. Capiya Publishing.

Yudiatmaja, W. E. (2013a). Ekonomi Kebijakan Penyelenggaraan Pendidikan bagi Anak Jalanan di Kota Padang. Jurnal Ilmu Administrasi Negara (JUAN), 1(1), 1-8.

Yudiatmaja, W. E. (2013b). Kebijakan dan Program Rehabilitasi dan Rekonstruksi Perumahan Pasca Erupsi Merapi Tahun 2010 di Kabupaten Sleman. Jurnal Ilmu Administrasi Negara (JUAN), 1(2), 1-12.

Yudiatmaja, W. E. (2016). Tata kelola pariwisata di Kecamatan Buru.

Yudiatmaja, W. E., Alfiandri, A., \& Hidayat, R. (2017). Far from fire: The service delivery 
quality gap plaguing Indonesian Ports. JKAP (Jurnal Kebijakan Dan Administrasi Publik), 21(1), 31-42.

Yudiatmaja, W. E., Safitri, D. P., \& Manalu, A. M. R. (2017). Inovasi kebijakan dan pemerintahan jaringan di era desentralisasi: Studi kasus Perda Kota Batam No. 4 Tahun 2015. Prosiding SNaPP2017 Sosial, Ekonomi, Dan Humaniora, 612-631. 